\title{
A study in the rat of the interaction between the effects of calcium and phosphorus content of the diet at two different levels and the presence or absence of vitamin $D$
}

\author{
By R. B. HARRAND, R. M. GREEN AND R. L. HAR'TLES \\ Department of Dental Sciences, School of Dental Surgery, \\ University of Liverpool
}

(Received 22 fune 1965-Accepted 23 August 1965)

\begin{abstract}
1. Four groups of weanling rats were maintained on diets containing either $0.12 \%$ or $0.24 \%$ of both calcium and phosphorus, in the presence and absence of added ergocalciferol. 2. Increase in mineral intake or the provision of vitamin $D$ increased the final body-weight, with a significant interaction between the two factors. 3. Serum $\mathrm{Ca}$ and $\mathrm{P}$ concentrations were raised significantly by both the vitamin and the increase in mineral intake without significant interaction. 4. Measurements were made of bone and tooth weights and ash values and of the length of the humeri. For only two measurements was there any interaction between the effect of vitamin D and increase in mineral intake, namely the length of the humeri, and their ash values expressed as a percentage of the dry fat-free weight. 5 . It is concluded that in relation to the amount of mineral deposited, the incisor tooth is more resistant to nutritional stress than is the bone.
\end{abstract}

It has long been realized that, provided the dietary intake of calcium and phosphorus is adequate in absolute and relative terms, the rat's requirement for vitamin $\mathrm{D}$ is very small (Irving, 1944-5, 1957). However, if the mineral intake is low or the $\mathrm{Ca}: \mathrm{P}$ ratio is disturbed the effect of vitamin $\mathrm{D}$ becomes more apparent (Hartles, Leaver \& Triffit, 1963, 1964; Ferguson \& Hartles, 1963, r964).

In the study now presented weanling rats were maintained on diets with or without added vitamin $\mathrm{D}$, with a $\mathrm{Ca}: \mathrm{P}$ ratio of $\mathrm{I} \cdot \mathrm{O}$, and containing $0.12 \% \mathrm{Ca}$ and $\mathrm{P}$, or $0.24 \%$ $\mathrm{Ca}$ and $\mathrm{P}$. There were therefore four treatments, namely minerals at two different dietary levels, in the presence and absence of vitamin D. Such an experiment is a $2^{2}$ factorial design and will yield a series of orthogonal comparisons concerning the effect of vitamin $D$, the effect of increased dietary mineral, and any interaction between the two. Measurements were made of final body-weight, serum $\mathrm{Ca}$ and $\mathrm{P}$, length, weight and ash content of the humeri, and weight and ash content of the incisor teeth. The effects of addition of vitamin $\mathrm{D}$ and of increasing dietary $\mathrm{Ca}$ and $\mathrm{P}$ content were separate and distinct except in relation to final body-weight, length of humeri and the ash content of the humeri expressed as a percentage of dry fat-free tissue. With these there was significant interaction.

\section{EXPERIMENTAL}

Animals. Forty black and white weanling rats (2I-24 days old) from our own colony were distributed in ten blocks of four animals each according to weight and sex. Thus there were five blocks of males and five of females, the weights of the animals within each block being as close together as possible. 
Treatments. One animal from each block was assigned to each of four treatment groups I, I D, 2 and $2 \mathrm{D}$, by the use of a table of random numbers. Each group consisted therefore of five male and five female rats.

Diets. The defined diets used were similar to those already described by Hartles \& Leaver (1961) but with a variation in the composition of the salt mixture. The nonmineral components of the diet, i.e. sucrose, albumin and groundnut oil, contained $0.026 \% \mathrm{Ca}$ and $0.06 \% \mathrm{P}$.

A basic salt mixture was prepared as follows; the salts were anhydrous unless otherwise indicated.

$\begin{array}{lrlr}\mathrm{KCl} & 650 \mathrm{~g} & \mathrm{MnSO}_{4} \cdot 4 \mathrm{H}_{2} \mathrm{O} & 7 \mathrm{~g} \\ \mathrm{NaCl} & 825 \mathrm{~g} & \mathrm{ZnCl}_{2} & 3 \mathrm{~g} \\ \mathrm{FeC}_{6} \cdot \mathrm{H}_{5} \mathrm{O}_{4} & 42 \mathrm{~g} & \mathrm{CuSO}_{4} \cdot 5 \mathrm{H}_{2} \mathrm{O} & \mathrm{I} \cdot 9 \mathrm{~g} \\ \mathrm{MgSO}_{4} & 75 \mathrm{~g} & \mathrm{KI} & \mathrm{I} \cdot 3 \mathrm{~g} \\ & & \mathrm{COCl}_{3} & 0.2 \mathrm{~g}\end{array}$

This mixture contains neither $\mathrm{Ca}$ nor $\mathrm{P}$, and each $960 \mathrm{~g}$ diet contained $4 \circ \mathrm{g}$ of the mixture. The addition of $0.875 \mathrm{~g} \mathrm{CaCO}_{3}$ raises the Ca content of the whole diet to $0.06 \%$, the same level as for $\mathrm{P}$. To raise the $\mathrm{Ca}$ and $\mathrm{P}$ content further a 'booster' salt mixture was prepared containing $100 \mathrm{~g} \mathrm{CaHPO}_{4}$ and $28.9 \mathrm{~g} \mathrm{KH}_{2} \mathrm{PO}_{4}$. Diets I and I D each contained $2.63 \mathrm{~g}$ 'booster' $/ \mathrm{kg}$, and diets 2 and $2 \mathrm{D} 7.9 \mathrm{~g} / \mathrm{kg}$. The main features of the four dietary treatments were:

$\begin{array}{cccc} & \mathrm{Ca} & \mathbf{P} & \begin{array}{c}\text { Ergocalciferol in } \\ 960 \mathrm{~g} \text { diet } \\ (\mu \mathrm{g})\end{array} \\ \text { Group } & (\%) & (\%) & \text { None } \\ \text { I } & 0.12 & 0.12 & 200 \\ \text { ID } & 0.12 & 0.12 & \text { None } \\ \text { 2 } & 0.24 & 0.24 & 200 \\ \text { 2D } & 0.24 & 0.24 & \end{array}$

Husbandry. The animals were housed in screen-bottomed wire cages, five of one sex to a cage, without access to direct sunlight and at a temperature of $2 \mathbf{I}-22^{\circ}$. They were given the diets and deionized water in unrestricted amounts and were weighed every 10 days.

Food intake. An estimate of the amount of each diet eaten was obtained by placing four animals at a time, one from each treatment, in individual metabolism cages for $24 \mathrm{~h}$ with a weighed amount of diet. The animals from each treatment were taken in a random order until each animal had spent one period of $24 \mathrm{~h}$ in a metabolism cage; this procedure was then repeated five times so that each animal on experiment spent six periods of $24 \mathrm{~h}$ in a metabolism cage. During each of the six cycles any one of the four metabolism cages used was assigned to one treatment but at the end of each cycle the treatments were reassigned to the cages, in random order, so that any bias due to the effect of a particular cage would be eliminated.

Duration of experiment. The animals were maintained on their respective diets for 60 days, anaesthetized by diethyl ether inhalation and killed by decapitation to enable blood to be collected.

Serum analysis. Determination of terminal serum $\mathrm{Ca}$ and inorganic $\mathbf{P}$ contents was carried out as described by Hartles et al. (1963). 
Bone and incisor tooth measurements. The humeri from each animal were dissected, stripped of all soft tissue and the fresh weight and maximum length determined. The humeri were then extracted in boiling ethanol in a Soxhlet extractor for $\mathrm{I} 8 \mathrm{~h}$, dried at $100^{\circ}$ for $3 \mathrm{~h}$ and weighed. The dry fat-free bones were ashed at $800^{\circ}$ to constant weight.

The lower incisor teeth were removed from each animal, extracted with ethanol, dried, weighed and ashed in the same way as for the bones.

Histological examinations. The femurs and upper incisor teeth were dissected, decalcified, sectioned and stained as described by Ferguson \& Hartles (I963, I964).

\section{RESULTS}

Weight and food intake. The terminal body-weights and the approximate food intakes for each group and the significance levels of the differences in final body-weights are given in Table $\mathrm{I}$.

Table 1 . Mean final body-weight $(g)$ of five $\delta$ and five trats and mean food intake per day $(g)$ during the experiment, together with significance levels of differences in weight gains in the four groups and of the interaction between the effects of vitamin $D$ and increased mineral intake

\begin{tabular}{|c|c|c|c|c|}
\hline & Final body- & Daily food & \multicolumn{2}{|c|}{$\begin{array}{l}\text { Significance levels for } \\
\text { differences in weight }\end{array}$} \\
\hline $\mathrm{I}$ & $135 \cdot 3$ & 10.4 & & \\
\hline I & $158 \cdot 9$ & 10.8 & Vitamint & $\pi$ \\
\hline 2 & $162 \cdot 6$ & 13.8 & Mineral & $P<0.001$ \\
\hline $2 \mathrm{D}$ & 166.5 & $15 \cdot 1$ & & \\
\hline Standard error & $7 \cdot 6$ & - & & \\
\hline
\end{tabular}

Blood, bones and teeth. The results for serum $\mathrm{Ca}$ and inorganic $\mathrm{P}$ contents, bone length, weight and ash content, and incisor weight and ash content are given in Table 2. These results were subjected to an analysis of variance in which the total treatment variation was divided into the portion due to the treatments, the portion due to the blocks and the residual or error variation. That part of the variation due to the treatments was then subdivided into that due to the vitamin $\mathrm{D}$, that due to the alteration in the $\mathrm{Ca}$ and $\mathrm{P}$ content, and that due to the interaction of these two factors. 'The test of significance used was Snedecor's $F$ test and the levels of significance attained are shown in Table 2.

Histological examination. The bones of group I animals were frankly rachitic with wide epiphysial cartilaginous zones, those of group I D were also rachitic but to a lesser degree. The bones of the rats in groups 2 and $2 \mathrm{D}$ were almost normal in appearance. The incisor dentine of group I animals showed changes similar to those reported by Ferguson \& Hartles (1964) in rats maintained on low-P and low-vitamin D diets; there was a lack of fusion of calcifying areas and some indication of wavy 
incremental lines. In group $\mathrm{I} D$, which received vitamin $\mathrm{D}$, the incremental pattern was more pronounced. In neither group was the width of predentine greatly increased. In the animals of group 2 the incremental pattern was less noticeable, and in group $2 \mathrm{D}$ the dentine appeared almost normal.

\section{Table 2. Effect of vitamin $D$ and mineral intake on the composition of serum, bones and teeth}

(Mean values with standard errors for groups of five $\delta$ and five $q$ rats, together with significance levels for the variation due to vitamin $D$, increased dietary mineral content and their interaction)

Serum $\mathrm{Ca}(\mu \mathrm{g} / \mathrm{ml})$

Serum $\mathrm{P}(\mu \mathrm{g} / \mathrm{ml})$

Fresh wt of paired

humeri (mg)

Dry fat-free wt of paired humeri (mg)

Wt of ash in paired

humeri (mg)

Ash as \% of fresh humeri

Ash as \% of dry fat-free

humeri

Length of humerus (mm)

Dry fat-free wt of lower

incisor (mg)

$\mathrm{Wt}$ of ash in lower incisor (mg)

Ash as $\%$ of dry fat-free

lower incisor

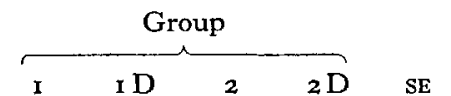
Significance levels
for effects of

\begin{tabular}{|c|c|c|c|c|c|c|c|}
\hline & & & & & & or effects $c$ & \\
\hline & & & & & Vitamin D & Minerals & Interaction \\
\hline I & $1 \mathrm{D}$ & 2 & $2 \mathrm{D}$ & SE & $(P)$ & $(P)$ & $(P)$ \\
\hline $72 \cdot 7$ & $9 x \cdot 3$ & $92 \cdot I$ & 103.4 & $4 \cdot 15$ & $<0.01$ & $<0.01$ & NS \\
\hline $43 \cdot 9$ & 63.9 & $7 x \cdot 1$ & $85 \cdot 4$ & $4 \cdot 32$ & $<0.001$ & $<0.001$ & NS \\
\hline $406 \cdot 1$ & $396 \cdot 0$ & $437^{\circ} 7$ & $419 \cdot 8$ & $5 \cdot$ I5 & $<0.05$ & $<0.001$ & NS \\
\hline $182 \cdot 1$ & $183 \cdot 2$ & $248 \cdot 6$ & $245^{\circ} 9$ & $7 \cdot 47$ & NS & $<0.001$ & NS \\
\hline $81 \cdot 7$ & $9 I \cdot I$ & $148 \cdot 2$ & 150.9 & $4 \cdot 78$ & $<0.025$ & $<0.001$ & $\mathrm{NS}$ \\
\hline $20 \cdot 3$ & $23 \cdot 2$ & 34.0 & $36 \cdot 0$ & 0.93 & $<0.001$ & $<0.001$ & NS \\
\hline $44 \cdot 8$ & 49.6 & $59 \cdot 6$ & $6 x \cdot 3$ & 0.94 & $<0.001$ & $<0.001$ & $<0.05$ \\
\hline $2 I \cdot O$ & 23.0 & 23.0 & $23 \cdot 0$ & $2 \cdot 96$ & $<0.001$ & $<0.001$ & $<0.001$ \\
\hline 53.9 & $55 \cdot 6$ & $59 \cdot 1$ & $59^{\cdot 6}$ & $1 \cdot 44$ & NS & $<0.001$ & NS \\
\hline $38 \cdot 4$ & $40 \cdot 0$ & $43 \cdot I$ & $43 \cdot 8$ & $I \cdot 10$ & NS & $<0.00 \mathrm{r}$ & NS \\
\hline $71 \cdot 2$ & $72 \cdot 0$ & $72 \cdot 8$ & $73 \cdot 6$ & 0.52 & NS & $<0.01$ & NS \\
\hline
\end{tabular}

NS, not significant.

\section{DISCUSSION}

When the diet contains $0.56 \% \mathrm{Ca}$ and $0.48 \% \mathrm{P}$ it is difficult to demonstrate unequivocally changes in the rat as a result of adding vitamin $\mathrm{D}$ to the diet (Ferguson \& Hartles, 1963).

In the study now described the dietary levels of both $\mathrm{Ca}$ and $\mathrm{P}$ were below the optimal in all the diets, and this is apparent from the observation that on the most complete of the diets (group $2 \mathrm{D}$ ) the serum $\mathrm{Ca}$ concentration was below that normally found for our strain of rat $(c . \mathrm{I} 20 \mu \mathrm{g} / \mathrm{ml})$. Because of this it was possible separately to determine the effects of adding vitamin $\mathrm{D}$ and of increasing the mineral intake. The provision of vitamin $\mathrm{D}$ increased the final body-weight, and the raising of the dietary mineral content also caused an increase in final body-weight. There was, however, a significant interaction (Table $\mathrm{r}$ ) between the growth-promoting effects of the vitamin and of the minerals. The serum $\mathrm{Ca}$ and phosphate concentrations were raised significantly by the addition of vitamin $\mathrm{D}$ at both levels of mineral intake, and also by raising the dietary mineral content in the presence and absence of added vitamin $D$. The results presented in Table 2 show that the effects of increase in dietary mineral 
and of the addition of vitamin $\mathrm{D}$ on the raising of serum $\mathrm{Ca}$ and phosphate concentrations are separate and independent effects in the conditions of the experiment: there was no significant interaction between the two variables.

At both levels of dietary mineral, vitamin D had the effect of reducing the fresh weight of the humeri, although at a low level of significance $(P<0.05)$. The addition of minerals, on the other hand, caused a highly significant increase in fresh weight $(P<0.00 \mathrm{r})$ irrespective of the presence or absence of vitamin $\mathrm{D}$. There was no significant interaction, the two effects being opposite, separate and distinct.

The length of the humerus was significantly increased by the addition of vitamin $\mathrm{D}$ to the diet with the lower mineral content, or by increasing the dietary mineral content. The length of the humerus (see Table 2 ) was identical for groups $\mathrm{ID}, 2$ and $2 \mathrm{D}$, so the provision of vitamin $\mathrm{D}$ and extra mineral together exert the same effect as either the vitamin or extra mineral separately.

On the dry fat-free weight of the humeri the vitamin had no significant effect, whereas the effect of increase in mineral was highly significant. It is possible to deduce from these results that, in relation to the mass of the humeri, vitamin $D$ reduces the fat and water content of the bone, but that the effect is at a comparatively low level of significance and is less than the effect caused by an increase in dietary mineral.

The absolute amount of ash in the humeri was increased by the addition of vitamin $\mathrm{D}(P<0.025)$, but the effect of increase in dietary mineral was quantitatively much greater and of higher significance $\left(P<0^{\circ} \cdot 00 r\right)$ : there was no significant interaction between the two effects.

When the ash is expressed as a percentage of the fresh weight of the humeri, both vitamin $\mathrm{D}$ and increased dietary mineral raised the values significantly, again without significant interaction. However, if the ash is expressed as a percentage of the weight of the dry fat-free humeri, the effects of the two factors are still highly significant, but there is a negative interaction between the two at a low level of significance $(P<0.05)$. Thus, in the circumstances of this experiment, and in relation to mineral deposition in bone, the effects of vitamin $\mathrm{D}$ and of increase in dietary mineral are additive except on the ash content expressed as a percentage of the dry fat-free humeri.

Relation between serum $C a$ and $P$ concentrations and mineralization of bone. The addition of vitamin $\mathrm{D}$ to the diet containing the lower level of minerals resulted in a significant rise in serum $\mathrm{Ca}$ and $\mathrm{P}$ concentrations and a small but significant rise in bone ash. The addition of minerals in the absence of added vitamin $\mathrm{D}$ resulted in a significant rise in $\mathrm{Ca}$ and $\mathrm{P}$ of the same order as that produced by the vitamin when added to the low-mineral diet, but the effect of the addition of mineral to the diet on the deposition of mineral in the bones was highly significant and quantitatively much greater than the effect of vitamin D. It can be deduced therefore that in the rat in conditions of suboptimal mineral nutrition, a major function of vitamin $\mathrm{D}$ is to maintain the highest possible levels of serum $\mathrm{Ca}$ and $\mathrm{P}$ in circumstances in which the skeleton is poorly mineralized, as in groups $I$ and $I D$, and also when the degree of mineralization approaches normality, as in groups 2 and $2 \mathrm{D}$.

It is difficult to believe that in the rat the only effect of the vitamin is to improve 
absorption of $\mathrm{Ca}$ from the gut, or that the concentration of $\mathrm{Ca}$ and phosphate in the serum is the sole arbiter of mineralization. In the animals of both groups 2 and $2 \mathrm{D}$ which received the higher level of dietary $\mathrm{Ca}$ and $\mathrm{P}$, the skeletons were well mineralized, and yet in the group 2 animals which did not receive vitamin $\mathrm{D}$ the serum $\mathrm{Ca}$ and phosphate concentrations were less than in the animals of group $2 \mathrm{D}$ who did receive the vitamin. It is not unreasonable to conclude that when the $\mathrm{Ca}$ and $\mathrm{P}$ content of the diet is suboptimal, vitamin $\mathrm{D}$ helps to raise the serum concentrations by mobilizing mineral from the skeleton.

In the incisor teeth there was no possibility of resorption or mobilization of mineral which had been deposited. The flow of mineral is in one direction only. The provision of vitamin $D$ had no significant effect on the dry fat-free weight or on the ash content of the teeth at either level of dietary mineral. On the other hand, increased mineral intake either in the presence or absence of vitamin $\mathrm{D}$ had a significant effect on both bones and teeth, although for the latter it was quantitatively small.

These results provide further evidence that in circumstances in which minerals are in short supply the teeth appear to have priority over bone. It is difficult to explain this priority merely on the grounds of 'one-way traffic' of mineral, although this is undoubtedly a factor in the situation. If the effect of vitamin $\mathrm{D}$ and mineral intake were solely due to the raising of serum $\mathrm{Ca}$ and $\mathrm{P}$ concentration, similar effects might be expected on the bones and teeth. This is not so, and the results provide some evidence to support the view that the local factors in mineralization differ in the teeth and bones. Although the quantitative changes in the teeth are much less than in the bones, histological examination showed considerable disorganization, especially in groups $\mathrm{I}$ and $\mathrm{I} \mathrm{D}$. Thus, even though the amount of mineral deposited in the growing incisor may be little changed, the manner of its deposition and the quality of the tissue formed are impaired. It seems reasonable to conclude therefore that both vitamin $D$ and mineral intake play a part in governing the pattern of mineralization of the predentine, for even at the lowest levels of serum Ca and P (group I) the mass of mineral deposited in the tooth was only slightly (although significantly) reduced.

\section{REFERENCES}

Ferguson, H. W. \& Hartles, R. L. (1963). Archs oral Biol. 8, 407.

Ferguson, H. W. \& Hartles, R. L. (1964). Archs oral Biol. 9, 447.

Hartles, R. L. \& Leaver, A. G. (196r). Archs oral Biol. 5, 38.

Hartles, R. L., Leaver, A. F. \& Triffitt, J. T (1963). Archs oral Biol. 8, 657.

Hartles, R. L., Leaver, A. G. \& Triffitt, J. T. (I964). Archs oral Biol. 9, 725.

Irving, J. T. (1944-5). F. Physiol., Lond., ro3, 9.

Irving, J. T. (1957). Calcium Metabolism. London: Methuen. 